\title{
Eating disorders among health science students at a university in southern Brazil
}

\author{
Transtornos alimentares em universitárias da área da saúde de universidade do sul do Brasil
}

\author{
Luiza do Nascimento Ghizoni Pereira ${ }^{1}$, Fabiana Schuelter Trevisol ${ }^{2}$, João Quevedo ${ }^{3}$, Luciano Kurtz Jornada ${ }^{4}$ \\ ${ }^{1}$ Médica. Universidade do Sul de Santa Catarina (UNISUL), Tubarão, SC, Brazil. ${ }^{2}$ Doutora. Professora, Curso de Medicina, UNISUL. ${ }^{3}$ Doutor. Professor e coordenador, \\ Programa de Pós-Graduação em Ciências da Saúde, Universidade do Extremo Sul Catarinense (UNESC), Criciúma, SC, Brazil. ${ }^{4}$ Mestre. Professor, Curso de Medicina, \\ UNISUL.
}

Financial support: The present study is the result of undergraduate research studies conducted at Universidade do Sul de Santa Catarina (UNISUL) and was financially supported by the Programa Unisul de Iniciação Científica (PUIC UNISUL).

\begin{abstract}
Objectives: To analyze eating disorders among female university students and to assess the frequency of bulimia nervosa, anorexia nervosa, and inappropriate weight loss strategies in this population.

Methods: The sample comprised 214 female university students attending different health science programs at a university in southern Brazil, aged over 18 years, assessed using self-administered questionnaires. The 26 -item version of the Eating Attitudes Test (EAT-26), the Bulimic Investigatory Test, Edinburgh (BITE), and a supplementary questionnaire covering data on weight status and inappropriate weight loss strategies were used to assess dietary abnormalities.

Results: Mean age ( \pm standard deviation) was $21 \pm 9.93$ years, and mean body mass index (BMI) was $21.1 \pm 2.59$. Among the respondents, $72.9 \%$ said they would like to weigh less, $29 \%$ reported the use of different weight loss methods (diuretics were the most common, followed by laxatives, amphetamine-derived drugs, and self-induced vomiting). With regard to EAT-26 scores, 22.4\% (95\%CI 17.7-27.1) revealed abnormal feeding patterns; BITE indicated that 9.8\% (95\% CI 6.5-13.1) were at risk for developing bulimia and 36.9\% (95\%CI 31.5-42.3) required clinical evaluation. Mean BMI was lower among students with normal scores on both tests, but no association was found between BMI and satisfaction with own weight.

Conclusion: There was a strong trend toward eating disorders in the health science students assessed, as demonstrated by EAT-26 and BITE scores; inadequate weight loss strategies are frequently used as well.
\end{abstract}

Keywords: Eating disorders, anorexia, bulimia, students, health occupations.

\section{Resumo}

Objetivos: Analisar a presença de transtornos alimentares em universitárias e avaliar a frequência dos quadros de bulimia, anorexia nervosa e estratégias inadequadas para emagrecimento na amostra estudada.

Métodos: Foram estudadas 214 universitárias matriculadas em diferentes cursos da área da saúde em uma universidade do sul do Brasil, com idade igual ou superior a 18 anos; a avaliação se deu por meio de questionários autoaplicáveis. A frequência de padrões alimentares anormais foi avaliada de acordo com os escores das versões em português do Eating Attitudes Test, versão de 26 itens (EAT-26), do Bulimic Investigatory Test, Edinburgh (BITE), e um questionário complementar com itens sobre a situação ponderal e estratégias inadequadas utilizadas para emagrecer.

Resultados: As estudantes tinham média ( \pm desvio padrão) de idade de $21 \pm 9,93$ anos e índice de massa corporal (IMC) médio de $21,1 \pm 2,59$. Entre as participantes, $72,9 \%$ afirmaram que gostariam de pesar menos e $29 \%$ relataram o uso de estratégias inadequadas para emagrecer (o uso de diurético foi o mais frequente, seguido de laxantes, derivados de anfetaminas e vômitos induzidos). De acordo com a pontuação do EAT-26, 22,4\% das estudantes (IC95\% 17,7-27,1) apresentaram padrão alimentar anormal. Já o BITE indicou que 9,8\% (IC95\% 6,5-13,1) se encontravam no grupo com grande possibilidade de bulimia e 36,9 (IC95\% 31,5-42,3) apresentavam necessidade de avaliação clínica. A média do IMC foi menor entre as universitárias com escores normais nos dois testes, porém não foi encontrada associação entre IMC e satisfação com o próprio peso.

Conclusões: Nas futuras profissionais da saúde avaliadas, houve uma alta taxa de tendência a transtornos alimentares, conforme evidenciado pelos escores do EAT-26 e do BITE; o uso frequente de técnicas inadequadas de emagrecimento também foi constatado.

Descritores: Transtornos alimentares, anorexia, bulimia, estudantes de ciências da saúde.

\section{Correspondence:}

Fabiana Schuelter Trevisol, Av. José Acácio Moreira, 787, Bairro Dehon, CEP 88704-900, Tubarão, SC, Brazil. Tel.: (48) 3622.1442. E-mail: fabiana.trevisol@unisul.br ou fastrevisol@gmail.com

No conflicts of interest declared concerning the publication of this article.

Copyright $(\odot$ Revista de Psiquiatria do Rio Grande do Sul - APRS

Submitted Jul 20, 2009. Accepted May 19, 2010. 


\section{Introduction}

Eating disorders are behavioral syndromes in which two main nosologic entities stand out: anorexia nervosa (AN) and bulimia nervosa (BN). Considered separately, these two disorders are closely related because they share the same psychopathology: a prevalent idea involving an obsessive fear of gaining weight and concerns about body shape, causing patients to engage in highly restrictive diets or to use inappropriate methods to achieve their ideal body. ${ }^{1}$

The term anorexia is of Greek origin: $a$ ( $\alpha$, prefix of negation), $n$ (link between two vowels) and orexis (appetite), thus meaning a lack of desire to eat. In the present days, the etymological sense of the term is not used to refer to $\mathrm{AN}$, since patients do not actually show loss of appetite even in advanced stages of the disease; rather, they deliberately refuse to eat in order to lose weight or for fear of getting fat, even when they are underweight, as part of a clinical situation classically described as body image distortion., ${ }^{2,3}$

In turn, $\mathrm{BN}$ is characterized by frequent episodes of binge eating, followed by exaggerated weight control behaviors, such as prolonged fasting, induced vomiting, use of laxatives or diuretics, or intense exercise. In BN, nutrition, weight concerns, and body shape prevail in the patient's thoughts, behaviors, and self-image. ${ }^{4}$ Eating disorders such as $\mathrm{AN}$ and $\mathrm{BN}$ have increased in frequency and importance, especially among adolescent girls and young adult women. It is estimated that $20 \%$ of young women may be at risk of developing these diseases, based on the presence of subclinical or precursor behaviors. ${ }^{5}$

Abnormal eating habits and inappropriate weight loss practices are related to personal dissatisfaction and low selfesteem and are commonly expressed by dissatisfaction with body weight. ${ }^{3,5}$ An increased incidence of eating disorders has been shown in an epidemiological study, concomitantly with a redefinition of female beauty standards, toward an increasingly thin body. The standard of beauty as portrayed by the media and in social interactions seems to exert a significant effect on women. Media products that convey an aesthetic standard seem, at the same time, to express and model social representations of female beauty, which may, in turn, have an effect on dietary restrictions. ${ }^{6}$

Social reinforcement from the family, friends, and the media upon teenagers and young female adults, encouraging them to have a thin body, reveals the presence of symptoms suggestive of eating disorders and predicts the onset of these symptoms in this population. ${ }^{7}$ The transition from adolescence to adulthood, which is the life cycle stage that most college students are experiencing, involves both individual and social tasks, such as definitions about their career, the selection of sexual partners, and lifestyle choices. This population is thus particularly vulnerable to prevailing social models and representations, whether they express it by joining such models or by opposing to them. ${ }^{6}$

Eating disorders are increasingly receiving a great deal of attention from health professionals because of the significant levels of morbidity and mortality involved. The personal and social damage inflicted to predominantly young individuals, the long and variable course of the disease, and the reserved prognosis require a more effective treatment planning strategy in addition to the adequate allocation of human and financial resources. These aspects have been motivating the conduction of epidemiological studies aimed at ensuring greater care with regard to the prevention and early diagnosis of these pathologies, as well as promoting improvements in the mental health of this population. ${ }^{8}$

Therefore, the objective of the present study was to investigate the presence of eating disorders, namely $\mathrm{AN}$ and/or BN, among university students, based on the scores of the 26-item version of the Eating Attitudes Test $(\text { EAT-26) })^{9}$ and the Bulimic Investigatory Test, Edinburgh (BITE) ${ }^{10}$ The use of inadequate weight loss strategies, such as induced vomiting and the use of medicines, and their relationship with body mass index (BMI), have also been investigated.

\section{Methods}

A cross-sectional epidemiological study was conducted in 2007 among female university students enrolled in psychology, physical education, pharmacy, nursing, nutrition, dentistry, and medicine programs at a university in Tubarão, state of Santa Catarina, southern Brazil. The total number of health science students at the institution was 2,644 , according to the information provided by course coordinators. Sample size was calculated considering a $5 \%$ prevalence of eating disorders, ${ }^{11}$ a $3 \%$ margin of error, and a 95\% confidence interval $(95 \% \mathrm{CI})$, which resulted in 188 participants. To this number we added a $14 \%$ margin of safety, and therefore a total of 214 students were surveyed. Inclusion criteria were: female sex, age above 18 years, presence in the classroom at questionnaire administration, and agreement to participate in the study. Participants who inadequately filled out the selfadministered questionnaires were excluded.

Study participants answered a questionnaire concerning personal data, including self-reported weight and height. Validated Portuguese versions of the EAT-26 and BITE questionnaires were the instruments used for data collection. EAT-26 was originally designed to identify dietary restriction behaviors, which is a characteristic of AN, e.g. dieting and fasting, as well as bulimic behaviors, such as excessive food intake and self-induced vomiting. Depending on the type of response obtained to the 26 questions of this test, the scores could range from 0 to 78 ; scores above 20 points were classified as likelihood of presenting abnormal eating behavior. ${ }^{9}$ In turn, the BITE instrument assesses predominantly bulimic behaviors, such as excessive food intake, self-induced vomiting, fasting, dieting, as well as the use of anorectics, laxatives, and diuretics. The instrument comprises 33 questions and two subscales of symptoms and 
severity. According to the scores obtained in the symptom scale, participants were classified into three groups: high $(\geq$ 20 points), medium (10 to 19 points), and low scores $(<10$ points), corresponding to abnormal eating habits, unusual eating habits, and absence of abnormal feeding behavior, respectively. The severity scale was used only in cases with a symptom scale score above 10 ; these subjects were classified into three groups: mild (below 5), moderate (from 5 to 9), and severe ( $\geq 10$ points) dietary abnormalities. ${ }^{10}$

After approval of the study by the coordinators of health science programs at the university where the study was conducted, and after permission of the class instructor, lessons were interrupted for about 10 minutes for data collection. The students were informed about the aims of the research and were asked to sign a free and informed consent form before filling out the self-administered questionnaires. About five students were randomly selected in each class to fill out the questionnaire after the class.

Data were entered using the EpiData Entry version 3.1 (EpiData Association, Odense, Denmark). Analyses were performed using the Statistical Package for the Social Sciences (SPSS), version 15.0. Pearson's chi-square test was used to analyze the associations, whereas differences between means were examined using one-way analysis of variance (ANOVA) and Tukey's post hoc test. Significance was set at 5\%.

\section{Results}

The age of students included in the sample ranged from 18 to 47 years, at a mean age $21 \pm 9.93$ years. Among the participants, $46(21.5 \%)$ were attending the medical school, $56(26.2 \%)$ were taking psychology, 31 (14.5\%) dentistry, $28(13.1 \%)$ pharmacy, $24(11.2 \%)$ physical education, 19 $(8.9 \%)$ nutrition, and 10 (4.7\%) nursing. Body weight ranged between 44 and $99 \mathrm{~kg}$, resulting in an average weight of 54.4 $\pm 7.86 \mathrm{~kg}$. BMI levels ranged between 16.2 and $38.3 \mathrm{~kg} / \mathrm{m}^{2}$ (mean BMI: $21.1 \pm 2.593 \mathrm{~kg} / \mathrm{m}^{2}$ ). Figure 1 shows BMI levels in the sample.

With regard to weight loss strategies, $13.6 \%$ of the students had already used amphetamines, $16.8 \%$ diuretics, $14 \%$ laxatives, and 3.3\% had induced vomiting; $29 \%$ of the students had used at least one of these methods. The frequency of use of each of these strategies is shown in Table 1.

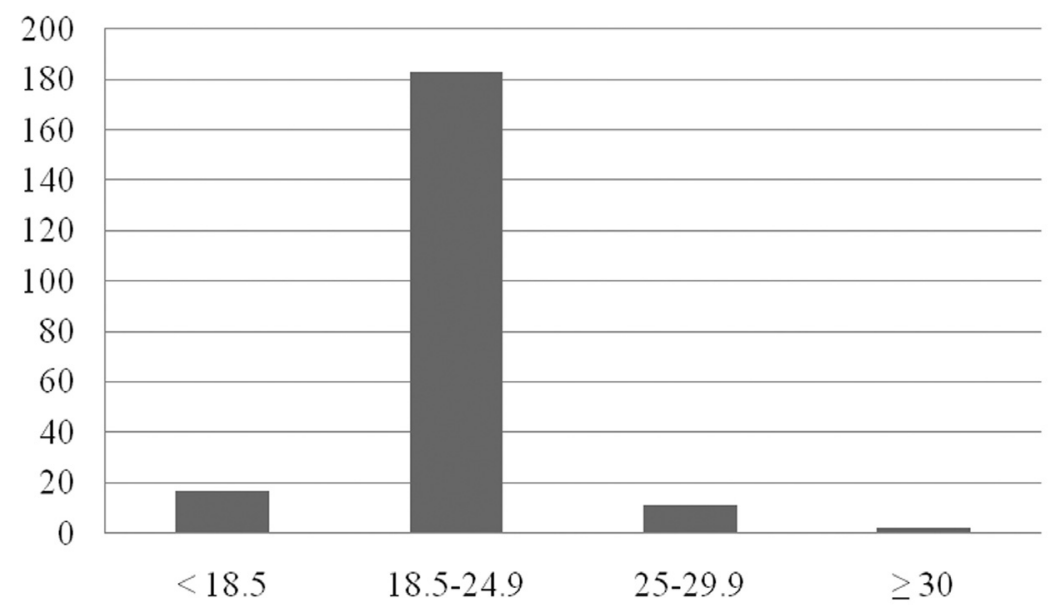

Figura 1 - Body mass index based on self-reported weight and height among health science students at a university in southern Brazil, 2007

Table 1 - Percentage frequency distribution of inadequate weight loss strategies used by health science students at a university in southern Brazil, 2007

\begin{tabular}{|c|c|c|c|c|c|c|}
\hline Weight loss strategies & Sometimes & Once a week & 2-3 times a week & Daily & 2-3 times a day & Total \\
\hline Amphetamines & 11.2 & 0.5 & - & 2.3 & 0.5 & 13.6 \\
\hline Diuretics & 13.6 & 0.9 & 0.9 & 1.4 & 0.5 & 16.8 \\
\hline Laxatives & 10.7 & 1.9 & 1.9 & - & - & 14.0 \\
\hline Induced vomiting & 1.9 & - & 0.9 & 0.5 & - & 3.3 \\
\hline
\end{tabular}


Among the interviewees, 59 (27.4\%) had already received professional guidance for weight loss, $9(4.2 \%)$ had participated in weight loss support groups, and 33 (15.4\%) claimed to have already had some type of eating disorder.

Table 2 presents the participants' perception on their weight and the association between BMI and the reported perceptions. When asked about the ideal weight, 155 (72.9\%) said they would like to weigh less, and $15 \%$ wished to weigh below normal health standards (based on the BMI calculated using the desired weight and the reported height). There was a statistically significant association between mean BMI and self-perception of body weight, i.e. students weighing less believed they were underweight, and students weighing more believed they were fat or too fat. However, this association was not observed between mean BMI and satisfaction with own body weight.

According to EAT-26 scores, 48 (22.4\%) participants showed abnormal eating patterns ( $>20$ points). BITE indicated that $21(9.8 \%)$ of the participants were at high risk of developing bulimia ( $\geq 20$ points) and that $79(36.9 \%)$ required clinical assessment through interviews (10-19 points). With regard to severity criteria, 24 (11.2\%) students showed moderate to severe symptoms ( $>5$ points), and 15 (7\%) showed severe dietary abnormalities ( $\geq 10$ points).

When assessing presence vs. absence of $\mathrm{BN}$ according to BITE scores, a higher mean BMI was found both in the group requiring diagnostic confirmation via interviews and in the group with confirmed BN. These data are shown in Table 3.

The association between self-evaluation of body weight and presence of eating disorders according to BITE and EAT26 is shown in Table 4. Because there was no trend toward eating disorders among university students who believed to be underweight, these students were excluded, thus allowing application of the chi-square test. There was a statistical association between feeling fat or too fat and presence of eating disorders based on the two instruments employed.

Table 2 - Comparison between mean BMI and body weight self-evaluation among health science students at a university in southern Brazil, 2007

\begin{tabular}{|c|c|c|c|c|}
\hline Feelings toward own weight & $\mathbf{n}$ & BMI $^{*}$ & ANOVA & $\mathbf{p}$ \\
\hline \multicolumn{5}{|l|}{ Body weight self-evaluation $^{\dagger}$} \\
\hline Underweight & 11 & 18.56 & & \\
\hline Normal weight & 157 & 20.64 & & \\
\hline Fat & 36 & 22.82 & & \\
\hline Very fat & 10 & 25.22 & $\mathrm{~F}=25.4$ & $<0.001$ \\
\hline \multicolumn{5}{|l|}{ Satisfaction with own weight } \\
\hline Wish to weigh more & 23 & 21.26 & & \\
\hline Wish to keep current weight & 32 & 20.64 & & \\
\hline Wish to weigh less & 155 & 21.21 & $F=0.665$ & 0.515 \\
\hline
\end{tabular}

ANOVA = one-way analysis of variance; BMI = body mass index

* BMI calculated from self-reported weight and height.

$\dagger$ Post hoc: BMI underweight $<$ normal weight $<$ fat $<$ very fat.

Table 3 - Comparison between presence of eating disorders according to BITE and EAT-26 scores and mean BMI among health science students at a university in southern Brazil, 2007

\begin{tabular}{lccc}
\hline Presence of eating disorders & $\mathbf{n}$ & BMI $^{*}$ & $\mathbf{p}$ \\
\hline According to BITE & & \\
$\quad$ No & & 20.32 & $<0.001^{\ddagger}$ \\
Diagnostic interview needed & 113 & 21.96 & \\
Yes & 79 & 22.22 & $0.012^{\S}$ \\
According to EAT-26 & 21 & 20.83 & 22.12 \\
No & 165 & 48 & \\
Yes & & & \\
\hline
\end{tabular}

$\mathrm{BMI}=$ body mass index

*BMI calculated from self-reported weight and height.

$\uparrow$ Post hoc: BMI no disorder $<$ BMI interview needed $=$ BMI disorder.

ANOVA, $\mathrm{F}=12.8$.

$\S$ Student $\mathrm{t}$ test, $\mathrm{T}=2.6$. 
Table 4 - Association between presence of eating disorders according to BITE and EAT-26 and body weight self-evaluation among health science students who considered themselves to be overweight or normal weight, southern Brazil, 2007

\begin{tabular}{lccc}
\hline & & Body weight self-evaluation & Fat/very fat (\%) \\
\cline { 2 - 4 } Presence of eating disorders & $\mathbf{n}$ & Normal weight (\%) & 3.9 \\
\hline According to BITE* & & & 96.1 \\
$\quad$ No & 103 & 65.8 & 34.2 \\
$\quad$ Diagnostic interview needed & 79 & 28.6 & 71.4 \\
$\quad$ Yes & 21 & 87.1 & 12.9 \\
According to EAT-26 & & 45.8 & 54.2 \\
$\quad$ No & 155 & 48 & \\
$\quad$ Yes & & & \\
\hline
\end{tabular}

${ }^{*}$ Chi-square test $=55.2 ; \mathrm{p} \leq 0.001$

${ }^{\dagger}$ Chi-square test $=35.6 ; \mathrm{p} \leq 0.001$

\section{Discussion}

In the present sample, the prevalence of abnormal eating habits, according to both EAT-26 (22.4\%) and BITE (36.9\% requiring diagnostic interview for confirmation and $9.8 \%$ at high risk for developing bulimia), was slightly higher than that found by other authors in the general population and among young women or university students. An estimated $20 \%$ of young women may be at risk for developing these pathologies because they present precursor or subclinical behavior. ${ }^{5}$ Studies conducted worldwide have shown a high prevalence of eating disorders among students: $11.4 \%$ in Egypt, ${ }^{12} 12.6 \%$ in Poland, ${ }^{13}$ and $11.7 \%$ in the Czech Republic. ${ }^{14}$ One study conducted in Brazil, assessing students from Ceará, found $5.5 \%$ of potential eating disorders according to EAT-26; in addition, 3.5\% were at high risk of developing these disorders and $23.1 \%$ required diagnostic confirmation according to BITE..$^{10}$ Another study conducted among women in Pelotas (RS) found a $16.6 \%$ incidence of eating disorders according to EAT-26 scores, whereas $30.4 \%$ of the patients presented unusual dietary patterns and $3.3 \%$ showed severely disrupted dietary patterns and compulsive eating according to BITE. ${ }^{5}$ Finally, a more recent study published in 2008, involving university students from Taubaté (SP), found prevalences of eating disorder symptoms of 10.3 and $14.1 \%$ for physical education and nutrition students, respectively, using EAT-26. ${ }^{15}$

The high prevalence of eating disorders observed in this study can probably be explained by the characteristics of our sample, namely, young university women living their selfaffirmation phase in different ways. In the Western culture, being slim means having competence, success, self-control and being sexually attractive $-\mathrm{a}$ thinness-oriented standard for female beauty that is part of the psychopathology of eating disorders.? Belonging to occupational groups such as athletes, dancers, models, and nutritionists reinforces the demand for a very thin body, thus increasing risk of developing eating disorders. It remains unclear whether the environment serves as a triggering factor or whether people already predisposed to developing eating disorders tend to seek those occupations. ${ }^{7}$ The high level of stress among health science students, caused by excessive working hours, curricular and extracurricular activities, and self-criticism may also have contributed to the higher rate of eating disorders found in this study when compared to those reported for other undergraduate programs. ${ }^{10}$

Abnormal eating habits and inadequate body weight control are associated with personal dissatisfaction and low self-esteem and are commonly expressed by body weight dissatisfaction., ${ }^{3,5}$ The association between feeling fat and presence of eating disorders has also been observed among medical students from Ceará. ${ }^{10}$ A study conducted in the general population in Pelotas (RS) found that body weight self-evaluation can increase by four times the risk of developing abnormal eating behavior among women who feel fat compared to those who feel thin or are normal weight. ${ }^{5}$ Another study conducted with physical education students in Rio de Janeiro (RJ) observed 20 times higher EAT-26 scores among students with body dissatisfaction according to the Body Shape Questionnaire (BSQ).${ }^{16}$ Finally, a qualitative study found that, among patients with eating disorders, the sensation of being obese is a common experience, suggesting that the onset concerns with weight and body dissatisfaction may not always be accompanied by actual weight excess. ${ }^{17} \mathrm{The}$ same study found an association between eating disorders and higher BMI means. However, the low number of overweight and obese individuals included in that sample reveals that, in fact, similar BMI means are observed among healthy individuals as well. Conversely, a study conducted by Nunes et al. reported that the crude effect of BMI carries a 1.86 greater risk for overweight and obese individuals to develop abnormal eating habits. ${ }^{5}$ All these data suggest that self-perception of body weight has a great impact on the development of eating behaviors and overrides the BMI effect. ${ }^{18}$

Our results regarding BMI and body self-evaluation are in accordance with international standards $(72.9 \%$ of the women in our study would like to weigh less). According to the literature, $70 \%$ of American women and $48 \%$ of Spanish women would like to be thinner, ${ }^{19}$ and $50 \%$ of Australian women would like to weigh $7 \mathrm{~kg}$ less..$^{20}$ National studies on the topic have shown that $28.1 \%$ of Brazilian medical students feel fat even when they are normal weight ${ }^{10}$; in addition, two thirds of the population assessed in Pelotas (RS) either would like to weigh less or feel fat, when in fact only one third of 
them were overweight or obese. ${ }^{5}$ Among nutrition university students, $18.6 \%$ were found to have a moderately or severely altered body self-image, even though $82.9 \%$ of them presented appropriate BMIs. ${ }^{21}$ Another study using a body image test found rates of 75 and $78 \%$ of dissatisfaction with body shape among physical education and nutrition students, respectively. ${ }^{15}$ These findings corroborate previous studies that confirm that many women are on diet and feel dissatisfied with their body even when they are not overweight. ${ }^{22}$ This may explain the absence of statistically significant associations between BMI and satisfaction with own weight when the self-reported weight of participants was compared to their desired weight. There was a statistically significant association between mean BMI and self-perception of body weight, i.e., although the participants in the study were dissatisfied with their body weight, no cases of body image distortion were observed (selfperception of body weight was consistent with mean BMI).

With regard to the prevalence of inappropriate weight loss strategies, a study conducted in the United States revealed that $23 \%$ of the women assessed used at least one of the methods, ${ }^{23}$ which is in accordance with the present results (29\%). A study conducted in the Czech Republic revealed that induced vomiting after meals was practiced by $6 \%$ of the studied population, whereas only $1 \%$ reported the use of laxatives or diuretics (5\% reported to have used these methods before). ${ }^{14}$ In our study, the most frequent weight loss strategy was the use of diuretics $(16.8 \%)$, followed by laxatives (14\%), amphetamines (13.6\%), and finally induced vomiting (3.3\%). These figures can be explained by a strong trend toward self-medication observed in Brazil. ${ }^{24}$ A study conducted among students in the state of Minas Gerais reported a prevalence of $10 \%$ of the use of at least one inappropriate weight control method, with a predominance of the use of laxatives. ${ }^{25}$

Some limitations of this study should be taken into consideration. Firstly, diagnosis of eating disorders was based solely on self-administered questionnaires, which is not sufficient to confirm the diagnosis of AN or BN (clinical examination is also required). Second, height and weight measurements were self-reported, which may have interfered with the results obtained, since eating disorders and body image distortion may lead to inaccurate measurements. Third, when patients were asked about the occurrence of previous eating problems, the type of disorder was not specified, hindering data analysis; the same limitation was observed in the questions on previous professional guidance for weight loss and participation in support groups (there was not information enough available for a conclusive analysis). Finally, the small number of respondents with overweight or obesity made a more detailed comparison between groups with different classifications of BMI unfeasible.

Further clinical research is recommended to improve our knowledge on the diagnosis and treatment of eating disorders among future health professionals, with a focus on prevention and awareness.

\section{Conclusion}

Our findings suggest that there was a strong trend toward eating disorders in the health science students assessed, as demonstrated by EAT-26 and BITE scores, and that inadequate weight loss strategies are frequently used in this population.

\section{References}

1. Claudino AM, Borges MBF. Critérios diagnósticos para transtornos alimentares: conceitos em evolução. Rev Bras Psiquiatr. 2002;24(3):7-12.

2. Cordás TA, Claudino AM. Transtornos alimentares: fundamentos históricos. Rev Bras Psiquiatr. 2004;24(3):3-6.

3. Saikali CJ, Soubhia CS, Scalfaro BM, Cordás TA. Imagem corporal nos transtornos alimentares. Rev Psiquiatr Clin. 2004;31(4):164-6.

4. Hay PJ. Understanding bulimia. Aust Fam Physician. 2007;36(9):708-12.

5. Nunes MA, Olinto MTA, Barros FC, Camey S. Influência da percepção do peso e do índice de massa corporal nos comportamentos alimentares anormais. Rev Bras Psiquiatr. 2001;23(1):21-7.

6. Vitolo MR, Bortolini GA, Horta RL. Prevalência de compulsão alimentar entre universitárias de diferentes áreas de estudo. Rev Psiquiatr Rio Gd Sul 2006;28(1):20-6.

7. Morgan $\mathrm{CM}$, Vecchiatti IR, Negrão $\mathrm{AB}$. Etiologia dos transtornos alimentares: aspectos biológicos, psicológicos e sócio-culturais. Rev Bras Psiquiatr. 2002;24(Suppl 3):18-23.

8. Alberton VC. Estudo da prevalência de comportamentos alimentares anormais em estudantes de Medicina da Universidade do Sul de Santa Catarina [monografia]. Tubarão: Universidade do Sul de Santa Catarina; 2005.

9. Nunes MA, Camey S, Olinto MTA, Mari JJ. The validity and 4-year test-retest reliability of the Brazilian version of the Eating Attitudes Test-26. Braz J Med Biol Res. 2005;38:1655-62.

10. Cordás TA, Hochgraf P. O BITE: instrumento para avaliação de bulimia nervosa - versão para o português. J Bras Psiquiatria. 1993;42:141-4

11. Souza FG, Martins MC, Monteiro RC, Neto GC, Ribeiro IB. Anorexia e bulimia nervosa em alunas da Faculdade de Medicina da Universidade Federal do Ceará - UFC. Rev Psiq Clin. 2002;29(4):172-80.

12. Nasser M. Screening for abnormal eating attitudes in a population of Egyptian secondary school girls. Soc Psychiatry Psychiatr Epidemiol. 1994;29(1):25-30.

13. Wlodarczyk-Bisaga K, Dolan B. A two-stage epidemiological study of abnormal eating attitudes and their prospective risk factors in Polish schoolgirls. Psychol Med. 1996;26(5):1021-32.

14. Janout V, Janoutova G. Eating disorders risk groups in the Czech Republic cross-sectional epidemiologic pilot study. Biomed Papers. 2004;148(2):189-93.

15. Gonçalves TD, Barbosa MP, Rosa LC, Rodrigues AM. Comportamento anoréxico e percepção corporal em universitários. J Bras Psiquiatr. 2008;57(3):166-70.

16. Bosi ML, Luiz RR, Uchimura KY, Oliveira FP. Comportamento alimentar e imagem corporal entre estudantes de educação física. J Bras Psiquiatr. 2008;57(1):28-33.

17. Souto S, Ferro-Bucher JS. Práticas indiscriminadas de dieta e emagrecimento e o desenvolvimento de transtornos alimentares. Rev Nutr Campinas. 2006;19(6):693-704.

18. Halmi K, Goldberg SC, Cunningham S. Perceptual distortion of body image in adolescent girls: distortion of body image in adolescence. Psychol Med. 1977;7(2):253-7.

19. Raich RM, Rosen JC, Deas J, Perez O, Requena A, Gross J. Eating disorder symptoms among adolescents in the United States and Spain: a comparative study. Int J Eat Disord. 1992;11(1):63-72.

20. Huon GF. Dieting, binge eating and some of their correlates among secondary school girls. Int J Eat Disord. 1994;15(2):159-64.

21. Bosi ML, Luiz RR, Morgado CM, Costa ML, Carvalho RJ. Autopercepção da imagem corporal em estudantes de nutrição: um estudo no município do Rio de Janeiro. J Bras Psiquiatr. 2006;55(2):108-13.

22. Cooper PJ, Taylor MJ, Cooper Z, Fairburn CG. The development and validation of the Body Shape Questionnaire. Int J Eat Disord. 1987;6:485-94.

23. Zuckerman DM, Colby A, Ware NC, Lazerson JS. The prevalence of bulimia among college students. Am J Public Health. 1986;76(9):1135-7.

24. Leite SN, Vieira M, Veber AP. Estudos de utilização de medicamentos: uma síntese de artigos publicados no Brasil e América Latina. Cienc Saude Coletiva. 2008;13(sup):793-802.

25. Vilela JE, Lamounier JA, Dellaretti Filho MA, Barros Neto JR, Horta GM Avaliação do comportamento alimentar em crianças e adolescentes de Belo Horizonte. Psiquiatr Biol. 2001;9(3):121-30. 